\author{
Bożena KUSZ ${ }^{1}$ \\ Janusz KILAR ${ }^{2}$ \\ Dariusz KUSZ ${ }^{3}$
}

\title{
SENSORY ATTRACTIVENESS OF LOCAL SMOKED BACONS
}

\begin{abstract}
The aim of the article was to evaluate the sensory attractiveness of local smoked bacon made from organic and traditional pig fattening feedstock. The research material consisted of three assortments of smoked bacon produced according to the same traditional recipe. The sensory attractiveness of the bacon was evaluated on the basis of the research of quality factors (external look, look on the cross-section, color, smell - intensity, smell - desirableness, taste, taste - intensity, taste - desirability) and affective reaction to the product. Two groups of people performed a direct assessment of the bacon: 115 consumers and a team of 12 experts. The research shows that the sensory quality of local smoked bacon differentiates significantly the feedstock used for their production. Of the three tested assortments of smoked bacon, the highest scores were awarded to the distinctions of the sensory quality of bacon from traditional fattening. The total sensory quality index of bacon from traditional fattening ranged from 4.28 to 4.50 points, bacon from intensive fattening from 3.66 to 3.95 points, and organic fattening bacon only from 3.20 to 3.42 points. This product ranking was mainly determined by two distinctive features: the cross-section look and the taste. In the opinion of consumers and experts the most-attractive local smoked bacon proved to be a product from pig fattening feedstock.
\end{abstract}

Keywords: local products, smoked bacon, sensory attractiveness.

\footnotetext{
${ }^{1}$ Dr inż. Bożena Kusz, Zakład Informatyki w Zarządzaniu, Wydział Zarządzania, Politechnika Rzeszowska im. Ignacego Łukasiewicza, Al. Powstańców Warszawy 8, 35-959 Rzeszów; autor korespondencyjny; e-mail: bozena.kusz@wp.pl.

Bożena Kusz, PhD Eng., Rzeszow University of Technology, Faculty of Management, Department of Computer Engineering in Management, 35-959 Rzeszów, Powstańców Warszawy Ave 12; coresponding author; e-mail: bozena.kusz@wp.pl.

${ }^{2}$ Dr inż. Janusz Kilar, Państwowa Wyższa Szkoła Zawodowa im. Stanisława Pigonia w Krośnie, ul. Rynek 1, 38-400 Krosno; e-mail: janusz.kilar@wp.pl Janusz Kilar, PhD Eng., State Higher Vocationel School Stanisława Pigonia in Krosno, ul. Rynek 1, 38-400 Krosno, e-mail: janusz.kilar@wp.pl

${ }^{3}$ Dr inż. Dariusz Kusz, Zakład Informatyki w Zarządzaniu, Wydział Zarządzania, Politechnika Rzeszowska im. Ignacego Łukasiewicza, Al. Powstańców Warszawy 8, 35-959 Rzeszów; e-mail: dkusz@prz.edu.pl

Dariusz Kusz, PhD Eng., Rzeszow University of Technology, Faculty of Management, Department of Computer Engineering in Management, 35-959 Rzeszów, Powstańców Warszawy Ave 12, e-mail: dkusz@prz.edu.pl
} 


\section{INTRODUCTION}

Local, regional and traditional products as well as organic foods sometimes referred to as niche ones are an increasing group of food products desired in the market. Although sales of this type of products, especially in our country, are still relatively small, they enjoy a growing interest. Local or regional products produced in a traditional way have an opinion of a high health standard, high quality and exceptional organoleptic properties with a unique taste. These characteristics differ significantly from conventional food, which, although it is standardized and safe, it rarely gives full satisfaction when eating.

Cold meats are still very popular among Polish consumers. In the structure of consumption of meat products, they constitute $76-80 \%{ }^{4}$. In the assortment groups of conventional products, sausages are most often consumed, and among the regional products the smoked ones ${ }^{5}$. The quality of meat products is shaped by technological, technical, economic, organizational and ethical factors. The quality of the feedstock is the key determinant ${ }^{6}$. However, in relation to local products, it was always the feedstock from the traditional farm pig fattening. Today, however, many meat plants, preserving the locality of recipes, produce these products from pork of various origins.

\section{THE PURPOSE OF THE RESEARCH}

The purpose of the study was to evaluate the sensory appeal of local smoked bacon made from organic and traditional pig fattening feedstock.

\section{MATERIAL AND METHODOLOGY OF RESEARCH}

The research material consisted of three assortments of smoked bacon made from the main part of the pork half - the bacon without ribs ${ }^{7}$. The feedstock for the production of bellies came from organic, traditional and intensive fattening pigs. The characteristics of selected pig fattening elements are shown in table 1.

Each assortment of smoked bacon was made of the feedstock from 16 carcasses, according to the same traditional recipe, while maintaining factory technological standards. Within 24 hours after smoking, individual samples of bacon from individual carcasses were collected from each assortment forming a pooled sample. The samples prepared in this way were vacuum packed and transported in refrigerated containers to the food analysis laboratory.

Sensory attractiveness of smoked bacon was evaluated on the basis of the research of quality factors and an affective reaction to the product. The following features were selected for the tests with assigned weighting factors: external look (0.05), cross-section look $(0.20)$, color (0.07), smell - intensity (0.05), smell - desirable (0.12)), taste $(0.21)$, taste - intensity $(0.10)$, taste- desirability $(0.20)$. When evaluating the factors, the point method was used in

\footnotetext{
${ }^{4}$ Mały Rocznik Statystyczny Polski, 2017.

${ }_{5}^{5}$ M. Ruda, B. Kusz, J. Kilar, D. Kusz, M. Kilar, Konsumenckie zainteresowanie wieprzowymi produktami regionalnymi na Podkarpaciu, PWSZ w Krośnie, Krosno 2016, s. 33.

${ }^{6}$ T. Blicharski (praca zbiorowa), Aktualna wartość dietetyczna wieprzowiny, jej znaczenie w diecie $i$ wptyw na zdrowie konsumentów, Warszawa 2013, s. 48.

7 A. Olszewski, Atlas rozbioru tusz zwierząt rzeźnych, Warszawa 2012, s. 45.
} 
a five-point scale of assessments ${ }^{8}$ where 1 point was the lowest grade and 5 points - the highest grade. For each factor the mean value and standard deviation were calculated, and the significance of the differences was checked using a one-way ANOVA and T-Tukey test. Taking into account the weighting coefficients, the total sensory quality indexes of the examined bacons were calculated. In the assessment of the affective reaction to the examined bacons, the degree of desirability and acceptance level were taken into account. The nine-degree hedonic scale was used to assess the desirability and acceptance. The degrees of the desirability scale were marked as: I love immensely; I really like; I quite like; I like it a bit; neither like nor dislike; I do not like a bit; I quite do not like; I really dislike; I do not like it very much. In turn the levels of acceptance were marked as: I am very happy; I am quite happy; it quite suits me; it suits me a little; it neither suits nor I accept it; it does not suit me; it quite does not suit me; I do not like it very much; I do not like it totally. When assessing the degree of desirability and acceptance, the following aspects were taken into account: look on cross-section, color, aroma and taste. After the evaluation, assigning numerical values from 1 to 9 to individual levels of desirability and acceptance rates, the general desirability and general acceptance of the tested smoked sides was calculated. In addition, a structure of indications of desirability grades and acceptance levels was determined. After examining the distinguishing features of sensory quality, degree of desirability and acceptance level, the evaluators chose the most attractive smoked bacon.

Table 1. Characteristics of selected pig fattening elements

\begin{tabular}{|l|l|l|l|}
\hline \multirow{2}{*}{ Specification } & \multicolumn{3}{|c|}{ Type of fattening } \\
\cline { 2 - 4 } & \multicolumn{1}{|c|}{ Ecological* } & \multicolumn{1}{c|}{ traditional } & \multicolumn{1}{c|}{ intense } \\
\hline $\begin{array}{l}\text { Racial origin of } \\
\text { fattening pigs }\end{array}$ & Polish slack white & Polish slack white & Polish slack white \\
\hline $\begin{array}{l}\text { Type of nutritional } \\
\text { dose }\end{array}$ & $\begin{array}{l}\text { dose with unbalanced } \\
\text { amount of energy and } \\
\text { nutrients }\end{array}$ & $\begin{array}{l}\text { dose with unbalanced } \\
\text { amount of energy and } \\
\text { nutrients }\end{array}$ & $\begin{array}{l}\text { balanced dose, } \\
\text { adapted to the } \\
\text { fattening phase }\end{array}$ \\
\hline $\begin{array}{l}\text { Feedstuffs used in } \\
\text { feeding pigs } \\
\text { spelled, rye, oat), corn, } \\
\text { pickled grains, pickled } \\
\text { potatoes, fodder beets, } \\
\text { nettle, pumpkin, fresh } \\
\text { whey, alfalfa, pasture; }\end{array}$ & $\begin{array}{l}\text { a farm-like concentrates } \\
\text { (barley meal, triticale, } \\
\text { field bean, post-extrac- } \\
\text { tion rapeseed, wheat } \\
\text { bran), pickled steamed } \\
\text { potatoes, fresh whey, } \\
\text { alfalfa, nettle; }\end{array}$ & $\begin{array}{l}\text { industrial complete } \\
\text { mixes starter and } \\
\text { fattening type }\end{array}$ \\
\hline
\end{tabular}

Ecological - *fattening process confirmed by the certificate of compliance of organic farming.

Two groups of people directly evaluated the tested smoked bacons: 115 consumers and a 12-person team trained in sensory evaluation of food products (at the paper, so-called "experts"). Consumers were selected using the convenient non-random selection method. There were 69 women and 46 men in this group. Taking into account the age, in the range of 18-35 years there were 66 people, in the range of 36-55 years - 31 people and over 55 years -18 people. In a selected group of consumers, 64 people lived in the countryside,

${ }^{8}$ PN-ISO 4121:1998, Analiza sensoryczna - Metodologia - Ocena produktów żywnościowych przy użyciu metod skalowania. 
34 in cities up to 50,000 residents, and 17 in cities over 50 thousand residents. Consumers assessed in the food analysis laboratory at the tables, and experts in sensory cabins. Each sample for testing was coded. Slices of bacon of $2 \mathrm{~mm}$ thick were served to the assessors covered on glass plates with an attached product evaluation card. The research in sensory cabins was performed twice.

Investigations of sensory quality and affective reaction to the product were made according to the rules given by Baryłko-Piekielna and Matuszewska ${ }^{9}$, according to PN-A/82007:1996 ${ }^{10}$, PN-ISO 5492:1997'11, PN-ISO 6658:1998 ${ }^{12}$, PN-ISO 5496:1997 $7^{13}$, PN-ISO 3972:1998 ${ }^{14}$ PN-ISO 8589:1998 ${ }^{15}$.

\section{THE RESULTS OF THE RESEARCH AND THEIR DISCUSSION}

The growing trend of the naturalness of food and the pleasure of its consumption is emphasizing the role of the sensory attractiveness of products ${ }^{16}$. The sensory qualities of smoked bacon are closely related to the specific layered arrangement of meat and fat in the feedstock used for its production ${ }^{17}$. The amount and thickness of layers of meat and fat in the bacon is most influenced by the nutrient during pig fattening ${ }^{18}$. Fat is a particularly important component of meat products because it is a carrier of taste, shapes their aromas and textural features, which affects the overall palatability of the product ${ }^{19}$. However, too thick layers of fat in the bacon increase not only its caloric value, but mainly reduce the interest in the finished product ${ }^{20}$.

The results of the evaluation of the sensory differences in the quality of local smoked bacon are summarized in table 2 .

It was found that consumers were given bacon an average of 4.01 to 4.30 points for the external look, and experts from 3.67 to 4.25 points. Both teams, with a slightly lower expert score, were the most likely to assess the external look of bacon from traditional fattening. In the consumers' opinion the look of bacon from traditional fattening was significantly

\footnotetext{
${ }^{2}$ N. Baryłko-Pikielna, I. Matuszewska, Sensoryczne badania żywności. Podstawy - Metody - Zastosowania, Warszawa 2009.

10 PN-A/82007:1996, Przetwory mięsne. Wędliny.

11 PN-ISO 5492:1997, Analiza sensoryczna - Terminologia.

12 PN-ISO 6658:1998, Analiza sensoryczna - Metodologia - Wytyczne ogólne.

13 PN-ISO 5496:1997, Analiza sensoryczna - Metodologia - Wprowadzenie i szkolenie oceniających w wykrywaniu i rozpoznawaniu zapachów.

14 PN-ISO 3972:1998, Analiza sensoryczna - Metodologia- Metoda sprawdzania wrażliwości smakowej.

15 PN-ISO 8589:1998, Analiza sensoryczna - Ogólne wytyczne dotyczące projektowania pracowni analizy sensorycznej.

${ }^{16}$ N. Baryłko-Pikielna, E. Kostyra, Wspótczesne trendy wyboru i akceptacji żywności, „Przemysł Spożywczy" 2004, t. 58, s. 31.

17 T. Blicharski (praca zbiorowa), Aktualna wartość dietetyczna wieprzowiny..., s. 40.

18 A. Kołodziej-Skalska, B. Matysiak, M. Grudziński, Mięso wieprzowe a zdrowie człowieka, KOSMOS Problemy Nauk Biologicznych 2016, t. 65, nr 4, s. 537.

${ }^{19} \mathrm{~S}$. Ventanas, E. Puolanne, H. Tuorila, Temporal changes of flavor and texture in cooked bologna type sausages as affected by fat and salt content, Meat Science 2010, 85, s. 415.

${ }^{20}$ I. Kowalczuk, B. Mikuta, B. Gronczyńska. Uwarunkowania zachowań konsumentów na rynku mięsa i przetworów. „Gospodarka Mięsna” 2002, 8, s. 36.
} 
more attractive in comparison with organic bacon, and in the opinion of experts in comparison with bacon from intensive fattening.

Another assessed characteristic of the sensory quality of the bacon was the cross-section look. This distinction, due to the specific nature of the product has a large impact on nutritional behaviors ${ }^{21}$. The scores awarded to the sides for the look on the cross-section confirm the significant effect of the origin of the feedstock (table 2). The look of bacon from traditional fattening turned out to be the most attractively shaped in the visual perception of consumers and experts. This distinction received the rating of 4.30 points. from consumers and 4.67 points from experts (table 2). The look on the cross-section of the other two bacon assortments were significantly $(\mathrm{p} \leq 0.05)$ lower $(\bar{x}=3.66$ points and $\bar{x}=3.08$ points - organic fattening bacon, $\bar{x}=3.92$ points and $\bar{x}=3.25$ points - bacon from intensive fattening). Similar effects on the look of the bacon on the cross-section of ecological and intense pig fattening factors were shown.

Table 2. Results of the evaluation of the distinguishing marks of the sensory quality of local smoked bacon (points)

\begin{tabular}{|c|c|c|c|c|c|c|c|c|c|c|c|c|}
\hline \multirow{3}{*}{ Quality factors } & \multicolumn{4}{|c|}{$\begin{array}{l}\text { Bacon from organic } \\
\text { fattening pigs }\end{array}$} & \multicolumn{4}{|c|}{$\begin{array}{l}\text { Bacon from traditional } \\
\text { fattening pigs }\end{array}$} & \multicolumn{4}{|c|}{$\begin{array}{l}\text { Bacon from intense } \\
\text { fattening pigs }\end{array}$} \\
\hline & \multicolumn{2}{|c|}{ consumers } & \multicolumn{2}{|c|}{ experts } & \multicolumn{2}{|c|}{ consumers } & \multicolumn{2}{|c|}{ experts } & \multicolumn{2}{|c|}{ consumers } & \multicolumn{2}{|c|}{ experts } \\
\hline & $\bar{x}$ & SD & $\overline{\bar{x}}$ & SD & $\bar{x}$ & SD & $\overline{\bar{x}}$ & $\mathrm{SD}$ & $\bar{x}$ & SD & $\bar{x}$ & SD \\
\hline External look & $4.01^{\mathrm{B}}$ & 0.96 & $4.00^{\mathrm{a}}$ & 0.95 & $4.30^{\mathrm{A}}$ & 0.74 & $4.25^{\mathrm{a}}$ & 0.87 & 4.09 & 0.80 & $3.67^{\mathrm{b}}$ & 0.65 \\
\hline $\begin{array}{l}\text { Look on the cross- } \\
\text { section }\end{array}$ & $3.66^{\mathrm{B}}$ & 1.03 & $3.08^{\mathrm{b}}$ & 0.67 & $4.30^{\mathrm{A}}$ & 0.76 & $4.67^{\mathrm{a}}$ & 0.65 & $3.92^{\mathrm{B}}$ & 0.95 & $3.25^{\mathrm{b}}$ & 0.97 \\
\hline Color & 3.81 & 0.92 & $3.25^{\mathrm{b}}$ & 0.97 & 4.25 & 0.71 & $4.42^{\mathrm{a}}$ & 0.79 & 4.06 & 0.81 & $3.67^{\mathrm{b}}$ & 0.78 \\
\hline Smell-intensity & 3.71 & 0.85 & $3.33^{\mathrm{b}}$ & 0.89 & 4.07 & 0.76 & $4.17^{\mathrm{a}}$ & 0.58 & 3.97 & 0.81 & $4.00^{\mathrm{a}}$ & 0.74 \\
\hline $\begin{array}{l}\text { Smell-desirable- } \\
\text { ness }\end{array}$ & $3.63^{\mathrm{B}}$ & 0.89 & $3.33^{\mathrm{b}}$ & 0.78 & $4.13^{\mathrm{A}}$ & 0.82 & $4.25^{\mathrm{a}}$ & 0.75 & $3.79^{\mathrm{B}}$ & 0.92 & $3.83^{\mathrm{a}}$ & 0.83 \\
\hline Taste & $3.61^{\mathrm{B}}$ & 1.07 & $3.00^{\mathrm{b}}$ & 1.04 & $4.40^{\mathrm{A}}$ & 0.80 & $4.83^{\mathrm{a}}$ & 0.58 & $3.94^{\mathrm{B}}$ & 0.87 & $3.58^{\mathrm{b}}$ & 0.67 \\
\hline Taste-intensity & $3.72^{\mathrm{B}}$ & 0.89 & $3.25^{\mathrm{b}}$ & 0.97 & $4.31^{\mathrm{A}}$ & 0.86 & $4.50^{\mathrm{a}}$ & 0.52 & $3.82^{\mathrm{B}}$ & 0.78 & $3.75^{\mathrm{b}}$ & 0.75 \\
\hline Taste-desirability & $3.69^{\mathrm{B}}$ & 0.98 & $3.17^{\mathrm{b}}$ & 0.72 & $4.30^{\mathrm{A}}$ & 0.88 & $4.33^{\mathrm{a}}$ & 0.65 & $3.84^{\mathrm{B}}$ & 0.93 & $3.92^{\mathrm{a}}$ & 0.90 \\
\hline
\end{tabular}

Average consumer ratings indicated in various large letters, and experts in lowercase letters differ significantly at $\mathrm{p} \leq 0.05$.

The color of bacon from organic fattening was rated lower $(\bar{x}=3.81$ points and $\bar{x}=3.25$ points) than from traditional fattening bacon $(\bar{x}=4.25$ points and $\bar{x}=4.42$ points $)$ and bacon from intensive fattening ( $\bar{x}=4.06$ points and $\bar{x}=3.67$ points). Significant differences in the assessment of the color of the bacon were noted in the group of experts. The most attractive color was characterized by bacon from traditional fattening (table 2).

Smell is a sensory distinction that affects pre-consumer stimulation of behaviors related to the acceptability of the product. For the scent analysis, the man uses the sense of smell. It is the oldest and most sensitive sense, and its place is the olfactory epithelium located in

${ }^{21}$ M. Grzybowska- Brzezińska, A. Rudzewicz, Wptyw marketingu sensorycznego na decyzje konsumentów (znaczenie zmystów), „Handel Wewnętrzny” 2013, 6(347), s. 74. 
the upper part of the nasal cavity. The smell of food products is analyzed in terms of specificity, intensity and desirability ${ }^{22}$. The research shows that the highest rating for the intensity and desirability of the smell was obtained from traditional fattening bacon. The second in the ranking of these distinctions was the bacon from intensive fattening, and the third from ecological fattening (table 2). The significant influence of the origin of the raw material on the shaping of the aroma intensity became visible in expert assessments. In relation to the desirable odor, significant differences were noted in both evaluation groups.

Taste is a phylogenetically old sense. Its role in cognitive processes was appreciated in antiquity, treating it equally with sight and smell. It is a very resistant to damage, hence its important role in assessing the sensory quality of food. Perception of taste is a sequence of complex biochemical molecular interactions that occur during stimulation with a flavor molecule and ultimately lead to the sensation of taste in the human brain. The basic flavors include: sweet, salty, sour and bitter. In recent years, the taste of umami and fat has also been isolated ${ }^{23}$. A bad or unacceptable taste eliminates the product from the consumer's diet. The rating of the bacon taste was varied depending on the origin of the feedstock and the group of evaluators. The taste rating of bacon granted by consumers ranged from $\bar{x}=3.61$ points. (ecological bacon bacon) to $\bar{x}=4.40$ points (traditional bacon bacon). The range of expert ratings was definitely wider. The taste of bacon from traditional fattening received an rating $\bar{x}=4.83$ points, and from an organic fattening only $\bar{x}=3.00$ points. Bacon tasting from traditional fattening was significantly higher compared to the assessment of bacon flavor from organic and intensive fattening. The differences observed in the taste assessment between bacon from organic and intensive fattening were negligible (table 2).

An important characteristic of the sensory assessment of the quality of food products is the palatability. It means a complex sensory-smell-sensory experience perceived when testing and consuming food. Strict taste sensations are supplemented and enriched with olfactory and tactile sensations that test the consistency or texture of the product ${ }^{24}$. The present study included the evaluation of the palatability of the bacon relative to its intensity and desirability. Both palatability attributes were highest evaluated in bacon from traditional fattening (from $\bar{x}=4.31$ to $\bar{x}=4.50$ points - intensity of flavor and from $\bar{x}=4.30$ to $\bar{x}=4.33$ points - desirability flavor). The lowest scores for palatability were given to organic bacon (from $\bar{x}=3.25$ to $\bar{x}=3.72$ points - intensity and from $\bar{x}=3.17$ to $\bar{x}=3.69$ points - desirable taste). Differences in the intensity and desirability ratings of bacon flavors were confirmed statistically. The bacon from traditional fattening was characterized by a much more attractive taste (table 2). The total sensory quality index measures the results of the point evaluation. According to the value of this index, the highest sensory quality was presented by bacon from traditional fattening (chart 1). However, it should be noted that in the case of bacon from organic and intensive fattening the index calculated from consumer ratings was higher than from expert ratings.

22 P. Rapiejko, Zmyst węchu, „Alergoprofil” 2006, Vol. 2, nr 4(7), s. 5-6.

23 A. Skolik, Smak w analizie sensorycznej, Poznań 2011, s. 18-20.

${ }^{24}$ N. Baryłko-Pikielna, Co nam oferuje zmyst smaku $i$ węchu, ,Przegląd Piekarski i Cukierniczy” 2004, 11, s. 2. 


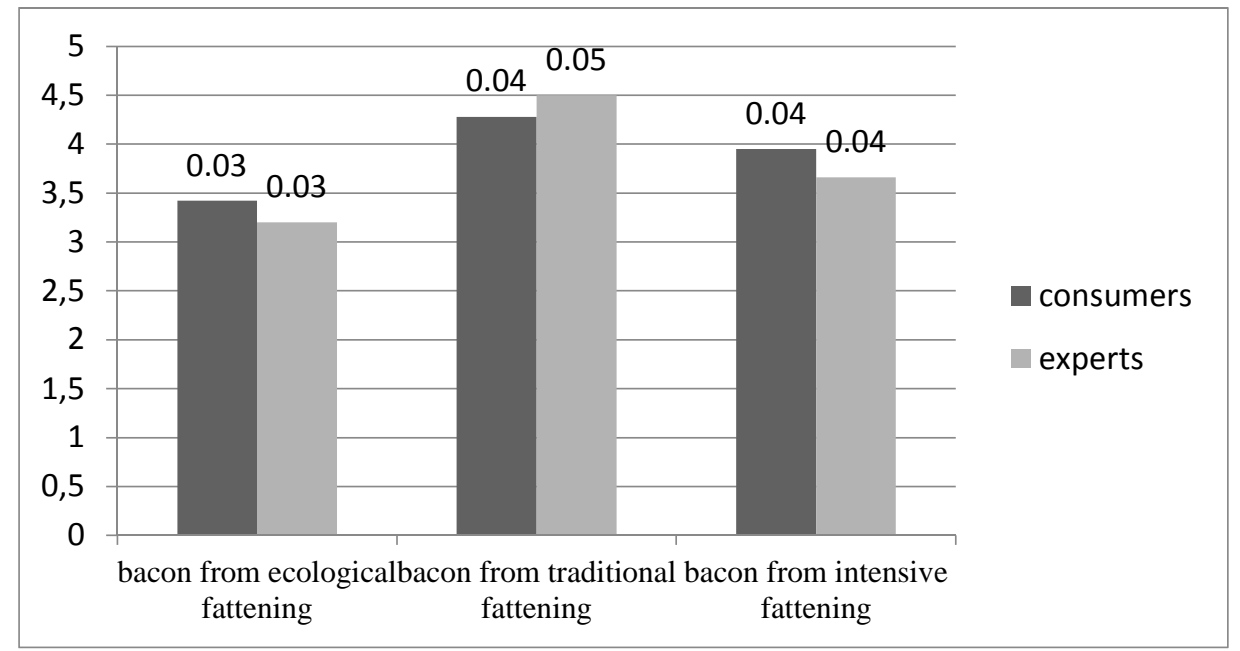

Chart 1 . Indicators of the sensory quality of the total local smoked bacon (points)

An overall evaluation of the desirability of tested bacon exposed by consumers was from 5.82 points (organic fattening bacon) to 7.43 points (traditional bacon). The experts gave the highest score ( 8.08 points) to the traditional fattening product and the lowest $(4.83$ points) to the intensive fattening product (chart 2). The data contained in table 3 shows that in the consumer group, organic fattening bacon had the most supporters on the level of desirability "I like medium", and in the group of experts "I like a little" and "neither like nor dislike". On the other hand, for bacon from traditional and intensive fattening, both groups of evaluators most often chose the level "I like very much".

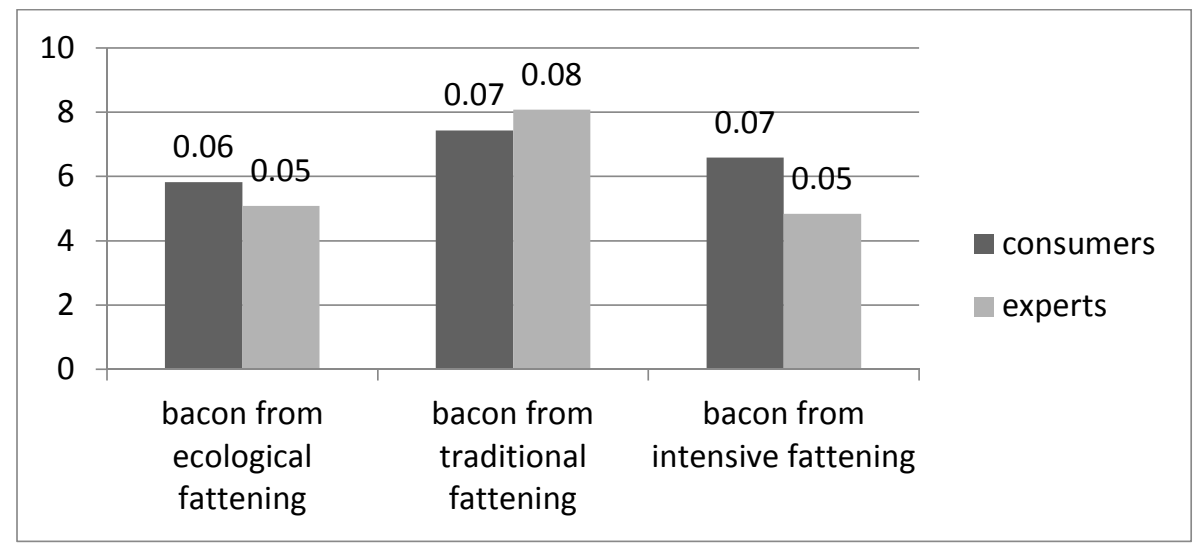

Chart 2. Overall assessment of the desirability of local smoked bacon (points)

Both teams expressed almost the same overall acceptance of bacon from traditional fattening (chart 3). 


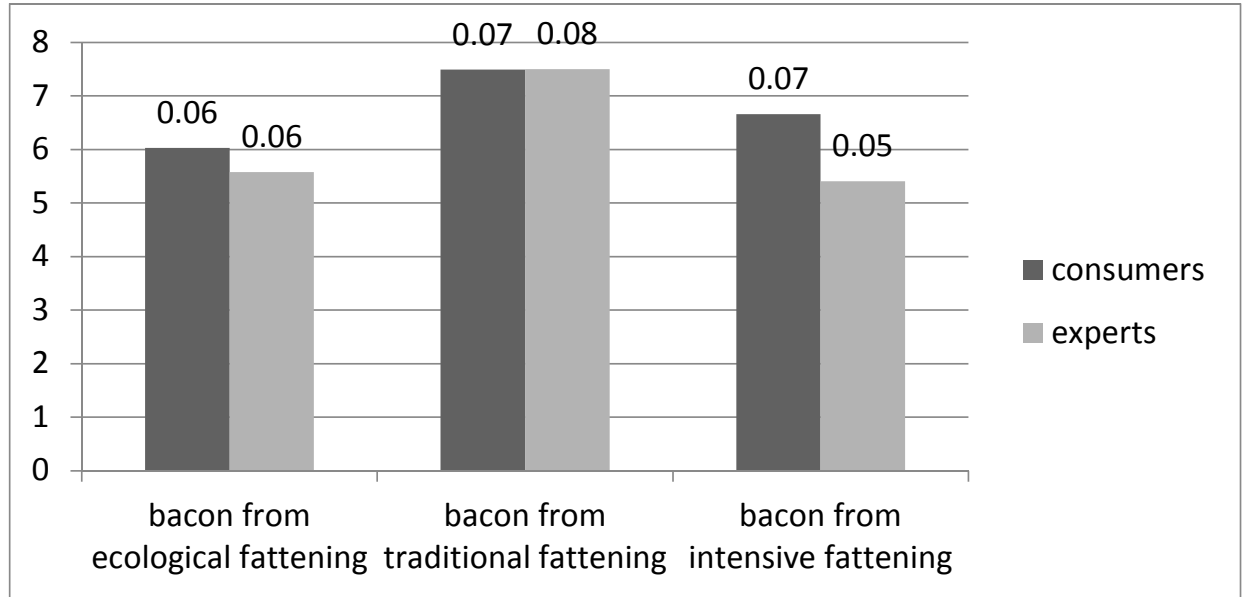

Chart 3. Overall assessment of the acceptance of local smoked bacon (points)

Table 3. Structure of indications of the degree of desirability and acceptance level of local smoked bacon (\%)

\begin{tabular}{|c|c|c|c|c|c|c|c|}
\hline & \multirow[t]{2}{*}{ Specification } & \multicolumn{2}{|c|}{$\begin{array}{l}\text { Bacon from ecolo- } \\
\text { gical fattening pigs }\end{array}$} & \multicolumn{2}{|c|}{$\begin{array}{l}\text { Bacon from tradi- } \\
\text { tional fattening pigs }\end{array}$} & \multicolumn{2}{|c|}{$\begin{array}{l}\text { Bacon from intense } \\
\text { fattening pigs }\end{array}$} \\
\hline & & consumers & experts & consumers & experts & consumers & experts \\
\hline \multirow{9}{*}{ 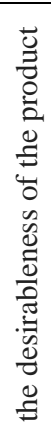 } & I love immensely & 7.83 & 0.00 & 24.35 & 33.33 & 7.83 & 0.00 \\
\hline & I really like & 17.39 & 0.00 & 33.91 & 41.67 & 31.30 & 41.67 \\
\hline & I quite like & 26.09 & 16.67 & 23.48 & 25.00 & 19.13 & 0.00 \\
\hline & I like it a bit & 9.57 & 25.00 & 8.70 & 0.00 & 21.74 & 0.00 \\
\hline & $\begin{array}{l}\text { Neither like nor dis- } \\
\text { like }\end{array}$ & 12.17 & 25.00 & 5.22 & 0.00 & 7.83 & 0.00 \\
\hline & I do not like a bite & 7.83 & 8.33 & 1.74 & 0.00 & 5.22 & 25.00 \\
\hline & I quite do not like & 5.22 & 8.33 & 0.00 & 0.00 & 1.74 & 8.33 \\
\hline & I really dislike & 11.30 & 16.67 & 0.00 & 0.00 & 3.48 & 25.00 \\
\hline & $\begin{array}{l}\text { I do not like very } \\
\text { much }\end{array}$ & 2.61 & 0.00 & 2.60 & 0.00 & 1.74 & 0.00 \\
\hline \multirow{9}{*}{ 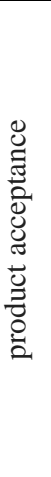 } & I am very happy & 10.43 & 8.33 & 24.35 & 25.00 & 10.43 & 0.00 \\
\hline & I am quite happy & 24.35 & 0.00 & 38.26 & 50.00 & 29.57 & 33.33 \\
\hline & It quite suits me & 17.39 & 25.00 & 19.13 & 8.33 & 20.87 & 8.33 \\
\hline & I suits me a little & 15.65 & 25.00 & 6.96 & 8.33 & 16.52 & 0.00 \\
\hline & $\begin{array}{l}\text { It neither suits nor } \\
\text { I accept it }\end{array}$ & 6.96 & 25.00 & 6.09 & 0.00 & 6.96 & 0.00 \\
\hline & It does not suit me & 6.09 & 0.00 & 0.87 & 0.00 & 6.96 & 33.33 \\
\hline & $\begin{array}{l}\text { It quite does not suit } \\
\text { me }\end{array}$ & 4.35 & 0.00 & 1.74 & 0.00 & 4.35 & 16.67 \\
\hline & $\begin{array}{l}\text { I do not like very } \\
\text { much }\end{array}$ & 12.17 & 16.67 & 0.87 & 8.33 & 1.74 & 8.33 \\
\hline & I do not like a totally & 2.61 & 0.00 & 1.74 & 0.00 & 2.61 & 0.00 \\
\hline
\end{tabular}


An overall assessment of acceptance of the remaining bacon was lower, with a clear differentiation of bacon from intensive fattening. The nature of the selection of the degree of acceptance of traditional and intensive fattening bacon was similar to the choice of the level of desirability (table 3). Regarding organic bacon, the majority of consumers accepted the "very good" level.

The research shows that both evaluation teams preferred bacon from traditional fattening (Figure 4). No one from the group of experts chose organic fattening bacon, and only $8,3 \%$ chose bacon from intensive fattening. However, in the consumer group, $13,9 \%$ chose bacon from organic fattening, and $27,0 \%$ bacon from intensive fattening

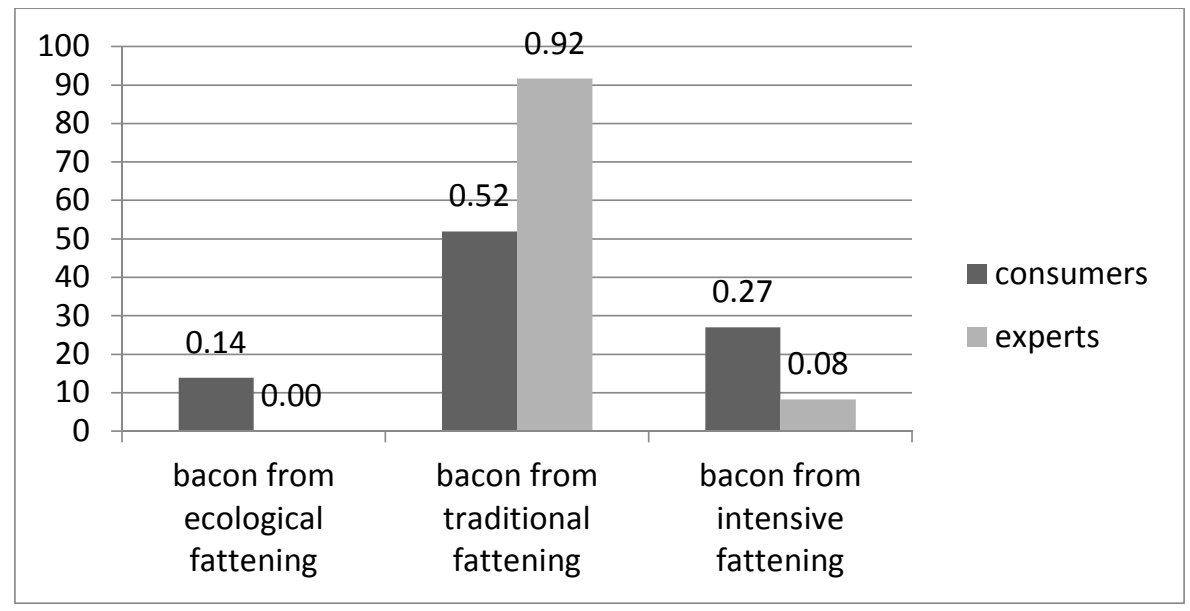

Chart 4. Evaluation of preferences of local smoked bacon (\%)

\section{STATEMENTS AND CONCLUSIONS}

1. The sensory quality of local smoked bacon significantly differentiates the feedstock used to make them.

2. Out of the three tested assortments of smoked bacon, the highest scores were awarded to the distinguishing factors of the sensory quality of bacon from traditional fattening.

3. Total sensory quality index of bacon from traditional fattening ranged from 4.28 to 4.50 points, bacon from intensive fattening from 3.66 to 3.95 points, and bacon from organic fattening only from 3.20 up to 3.42 points. This product ranking was mainly determined by two distinctive features: cross-section look and taste.

4. In the opinion of consumers and experts, the most-attractive local smoked bacon turned out to be a product from the pig fattening feedstock.

\section{REFERENCES}

1. Baryłko-Pikielna N., Co nam oferuje zmyst smaku i węchu, „Przegląd Piekarski i Cukierniczy” 2004, 11. 
2. Baryłko-Pikielna N., Kostyra E., Wspótczesne trendy wyboru i akceptacji żywności, „Przemysł Spożywczy” 2004, t. 58.

3. Baryłko-Pikielna N., Matuszewska I., Sensoryczne badania żywności Podstawy-MetodyZastosowania, Wydawnictwo Naukowe PTTŻ, Warszawa 2009.

4. Blicharski T. (praca zbiorowa), Aktualna wartość dietetyczna wieprzowiny, jej znaczenie $w$ diecie $i$ wptyw na zdrowie konsumentów, Warszawa 2013.

5. Grzybowska-Brzezińska M., Rudzewicz A., Wpływ marketingu sensorycznego na decyzje konsumentów (znaczenie zmystów), „Handel Wewnętrzny” 2013, 6(347).

6. Kołodziej-Skalska A, Matysiak B, Grudziński M., Mięso wieprzowe a zdrowie człowieka, KOSMOS Problemy Nauk Biologicznych, 2016, t. 65, 4.

7. Kowalczuk I, Mikuta B, Gronczyńska B., Uwarunkowania zachowań konsumentów na rynku mięsa i przetworów, „Gospodarka Mięsna” 2002, 8.

8. Mały Rocznik Statystyczny Polski, GUS, Warszawa 2017.

9. Olszewski A., Atlas rozbioru tusz zwierząt rzeźnych, Wydawnictwo WNT, Warszawa 2012.

10. PN-A/82007:1996, Przetwory mięsne. Wędliny.

11. PN-ISO 3972:1998, Analiza sensoryczna - Metodologia - Metoda sprawdzania wrażliwości smakowej.

12. PN-ISO 4121:1998, Analiza sensoryczna - Metodologia - Ocena produktów żywnościowych przy użyciu metod skalowania.

13. PN-ISO 5492:1997, Analiza sensoryczna - Terminologia.

14. PN-ISO 5496:1997, Analiza sensoryczna - Metodologia - Wprowadzenie i szkolenie oceniających w wykrywaniu i rozpoznawaniu zapachów.

15. PN-ISO 6658:1998, Analiza sensoryczna - Metodologia - Wytyczne ogólne.

16. PN-ISO 8589:1998, Analiza sensoryczna - Ogólne wytyczne dotyczące projektowania pracowni analizy sensorycznej.

17. Rapiejko P., Zmyst węchu, „Alergoprofil” 2006, t. 2, 4(7).

18. Ruda M., Kusz B., Kilar J., Kusz D., Kilar M., Konsumenckie zainteresowanie wieprzowymi produktami regionalnymi na Podkarpaciu, Krosno 2016.

19. Skolik A., Smak $w$ analizie sensorycznej, Wydawnictwo Uniwersytetu Ekonomicznego w Poznaniu, Poznań 2011.

20. Ventanas S., Puolanne E., Tuorila H., Temporal changes of flavor and texture in cooked bologna type sausages as affected by fat and salt content, "Meat Science" 2010, 85.

\section{SENSORYCZNA ATRAKCYJNOŚĆ LOKALNYCH BOCZKÓW WĘDZONYCH}

Celem badań była ocena sensorycznej atrakcyjności lokalnych boczków wędzonych wyrabianych z surowca z ekologicznego, tradycyjnego i intensywnego tuczu świń. Materiał badawczy stanowiły trzy sortymenty lokalnego boczku wędzonego z regionu Podkarpacia. Sensoryczną atrakcyjność boczków oceniano na podstawie badań wyróżników jakości (wygląd zewnętrzny, wygląd na przekroju, barwa, zapach - natężenie, zapach - pożądalność, smak, smakowitość - natężenie, smakowitość - pożądalność) i afektywnej reakcji na produkt. Wyróżniki jakości oceniano metodą punktową w skali od 1 (ocena najniższa) do 5 (ocena najwyższa). Zaś do oceny stopnia pożądalności i poziomu akceptacji badanych boczków zastosowano 9-stopniową skalę hedoniczną. Bezpośrednią ocenę boczków wykonywały dwie grupy osób: 115 konsumentów i 12-osobowy zespół ekspertów. Z badań wynika, że 
sensoryczną jakość lokalnych boczków wędzonych istotnie różnicuje surowiec wykorzystywany do ich wyrobu. Spośród trzech badanych sortymentów boczku wędzonego najwyższe oceny punktowe przyznawano $(\mathrm{p} \leq 0,05)$ wyróżnikom sensorycznej jakości boczku z tradycyjnego tuczu. Wskaźnik sensorycznej jakości całkowitej (WSJC) boczku z tradycyjnego tuczu wynosił od 4,28 do 4,50 pkt, boczku z intensywnego tuczu od 3,66 do 3,95 pkt, a boczku z ekologicznego tuczu tylko od 3,20 do 3,42 pkt. O takim rankingu produktów zdecydowały głównie dwa wyróżniki: wygląd na przekroju i smak. W ocenie konsumentów i ekspertów sensorycznie najatrakcyjniejszym lokalnym boczkiem wędzonym okazał się produkt z surowca z tradycyjnego tuczu świń.

Słowa kluczowe: produkty lokalne, boczek wędzony, sensoryczna atrakcyjność.

DOI: $10.7862 /$ rz.2018.mmr.31

Tekst złożono do redakcji: czerwiec 2018 r.

Tekst przyjęto do druku: wrzesień $2018 \mathrm{r}$. 
